\title{
Spatial variability of sugarcane row gaps: measurement and mapping
}

\section{Variabilidade espacial de falhas em cana-de-açúcar: mensuração e mapeamento}

\author{
José Paulo Molin¹, João Paulo Soto Veiga ${ }^{1 *}$
}

'Universidade de São Paulo/USP, Departamento de Engenharia de Biossistemas, Piracicaba, SP, Brazil

*Corresponding author: jpsveiga@usp.br

Received in december 11, 2015 and approved in february 29, 2016

\begin{abstract}
Sugarcane is a very important crop in Brazil, used as food production and biofuel, providing $18 \%$ of the total primary energy in the country. An important requirement to high yield is a good uniformity in the sugarcane field, which is impaired due to row gaps that appear since the first year of sugarcane crop caused by planting failures, harvesting damages, machinery traffic, pests, diseases and others. The aim of this study is to develop a system based on a photoelectric sensor to scan the field, georeferencing gaps representing them as a map. A data logger integrates the data from the photoelectric sensors, an encoder and a Global Navigation Satellite System (GNSS) and measures the distance between plants, defining the gaps. Tests under controlled conditions, using regular obstacles simulating stalks, showed errors between 0.02 and $0.03 \mathrm{~m}$ under speeds varying from 1.3 to $3.0 \mathrm{~m} \mathrm{~s}^{-1}$ and obstacles ranging from 0.1 to $1.0 \mathrm{~m}$ of gap. Results of tests performed at sugar cane rows were close to manual measurement. Field tests were performed using sampling plots of $6.0 \times 6.0 \mathrm{~m}$ (four crop rows) along the area, on newly planted and on ratoon areas, showed a good relation with manual measurements. The raw data provides the length of the individual gaps or its local percentage and the interpolation among punctual gaps produces a map highlighting areas with low and high gap intensity as a useful tool in the sugarcane management for decision making for local or integral replanting.
\end{abstract}

Index terms: Close range remote sensing; interpolation; photoelectric sensor; biofuel; field quality.

\section{RESUMO}

A cana-de-açúcar é uma cultura muito importante para o Brasil, usada para a produção, tanto de alimentos, quanto de biocombustíveis, provendo $18 \%$ do total de energia primária no país. Um importante requisito para uma produtividade alta é uma boa uniformidade do canavial, a qual é comprometida devido a falhas que aparecem nas linhas de cana causadas por falhas no plantio, danos durante a colheita, tráfego de máquinas, pragas e doenças entre outros fatores. O objetivo deste estudo é desenvolver um sistema baseado em um sensor fotoelétrico para examinar o canavial, georreferenciando as falhas e apresentando-as em um mapa. Um coletor de dados integrou um sensor fotoelétrico, um encoder um Sistema de Navegação Global por Satélites (GNSS em inglês) mensurando a distância entre as plantas, definindo as falhas. Testes em situação controlada, utilizando estacas, mostraram erros entre 0,02 e 0,03 m variando a velocidade de 1,3 a 3,0 $\mathrm{m} \mathrm{s}^{-1}$ e as estacas de 0,1 a 1,0 m de espaçamento, os resultados encontrados foram próximos aos mensurados manualmente. Testes em campo utilizando amostras de 6,0 × 6,0 m (quatro linhas de cana) em cana planta e soqueira, também mostraram uma boa relação com a mensuração manual. Os dados brutos fornecem o tamanho de cada falha individualmente ou em porcentagem e uma interpolação entre falhas pontuais produz um mapa que evidencia áreas com baixa ou alta densidade de falhas, criando uma ferramenta útil no gerenciamento da cultura de cana-de-açúcar para que sejam tomadas as medidas necessárias a manutenção do canavial.

Termos para indexação: Sensoriamento remote próximo; interpolação; sensor fotoelétrico; biocombustível; qualidade na lavoura.

\section{INTRODUCTION}

Sugarcane is responsible for $80 \%$ of the sugar produced in the world and it is cultivated in approximately $26.1 \times 106$ ha $(F A O, 2013)$ around the world. Brazil is the largest producer with 9.8x106 ha. In Brazil sugarcane crops are also important as raw material to produce fuel ethanol and electricity, accounting for $18.1 \%$ of the total primary energy produced in the country, reducing fossil fuel use and offsetting carbon (Pacca; Moreira, 2009; Rudorff et al., 2010; Wang et al., 2014; EPE, 2015).

Sugarcane fields are renewed, in average, each five years and an important parameter that is monitored to indicate planting quality are gaps caused by problems during planting operation (e.g. failures on stalks deposition, pests, dry weather, erosion, etc) as economic return greatly depends on a good stand along the years. 
With the mechanized planting of sugarcane becoming more popular and disseminated among producers, it is expected more field gaps since the planting operation, due to eye billets damage arising from mechanical harvest, handling and transportation of billets (Serafim et al., 2013). The gaps also likely become often and on a higher density, intensified by mechanical harvesting, as sugarcane fields become older (Santos et al., 2013).

Related to harvester interactions with the sugarcane plant, Ma et al. (2014) discuss about the cutting quality on stalks and stools and how it is critically important to reduce losses and to avoid the possibility of a reduction in ratoon due to stubble damage rates. In their review, parameters as blades velocity, cutting disc angle, cutting head movement, blades shape and the machine forward speed, have influence on the cutting quality, demonstrating how difficult the harvest process is and how it can affect the next yield.

Previous studies of rhizome damages found that between 10 and $27 \%$ of the rhizomes evaluated not have some kind of damage with almost half of the rhizomes showing small or large damages, leading to the occurrence of more infections, diseases and rhizome death (Manhães et al., 2013; Noronha et al., 2011). Soil compaction, especially on clay soils, is increased due to traffic over the rows, and has a strong relationship with sugarcane crop longevity and yield, which means that it may need to be replanted sooner than expected (Otto et al., 2011; Paula; Molin, 2013; Souza et al., 2012; Tolon-Becerra et al., 2011).

Gaps on sugarcane crops are considered as a distance between two consecutive stalks along the sugarcane row, and measured at the soil level from the center of the stalks (Stolf, 1986). This distance was originally proposed as $0.5 \mathrm{~m}$, but it may vary among producers and regions. It is usually taken manually by a team which walks through the fields measuring gaps on predetermined points (field samples), and expressing results as a percentage of gaps in relation with the total sugarcane row distance.

At annual crops like maize, the stand management is widely studied and losses of 62 to $84 \mathrm{~kg} \mathrm{ha}^{-1}$ can happen for each $0.01 \mathrm{~m}$ of standard deviation increased in the row spacing (Shi et al., 2015). It is a very important subject which cannot be neglected. In such cases, monitoring is done by seed sensors during the sowing operation or after the seedling, by ground-based vehicles or drones, counting plants and measuring distances using infrared, capacitance sensors, top images LiDAR, among other sensors (Nakarmi; Tang, 2012; Shi et al. 2015).

Johansen et al. (2014) used high spatial resolution images and developed a mapping approach to detect areas with potential cane grub damages, possibly reducing time and costs of identifying and deal dealing with these infected areas.

Knowledge on the spatial location and extent of sugarcane field gaps can facilitate the assessment of where it is more likely to occur and hence where rigorous attention must be paid at crop practices. Optical sensors that measure crop reflectance have been used to estimate sugarcane gaps (Frasson et al., 2007) and, associated with geographic coordinates obtained from a GNSS receiver, had led to very useful information that allows locating where there are gaps, inducing a quick action to correct it by replanting.

Monitoring combined with georeferencing can be done associated with routine operations, and can cover larger areas than the manual measuring. It requires modeling the spatial variability through geostatistical assessments and interpolation, enabling acquiring massive data transformed into useful information about the whole field and not only from sampling locations.

Images offer almost the same solution but have limitations regarding resolution as the data is collected from the top and leaves, at the time of monitoring, can cover and create confusion for the detection of individual plants. So the aim of this work is to validate a sensor dedicated for measuring sugarcane gaps and represent its data spatially.

\section{MATERIAL AND METHODS}

A photoelectric sensor BA2M-DDT (Autonics, Yangsan, Si, Korea) was used, horizontally positioned, to detect stalks. It has a LED infrared light source, with an adjusted sensitivity to up to $2.0 \mathrm{~m}$ of distance to the target, working at $4 \mathrm{~Hz}$ with $1 \mathrm{~ms}$ approximate response time. It was integrated to a data logger CR1000 (Campbell Scientific, Logan, Utah, USA) together with 240 cycles per revolution encoder (Hohner, Artur Nogueira, SP, Brazil) installed on a tractor non activated front wheel, composing the gap measuring system. This system has a L1 GPS receiver (AG 132, Trimble, Sunnyvale, California, USA), georeferencing to the generated data. A dedicated code on the data logger established the communication and the calculations of spacing between stalks intervals.

To validate the prototype, a test was established using regular obstacles simulating stalks (Figure 1). Wood stakes with varying widths $(0.05,0.10$ and $0.20 \mathrm{~m})$ were put stand in the ground with distances of $0.1,0.2,0.4$, $0.6,0.8$ and $1.0 \mathrm{~m}$ between each other. The sensor was mounted in the front of a tractor running at speeds of 1.3, 
1.8 and $3.0 \mathrm{~m} \mathrm{~s}^{-1}$ and the test was repeated six times for each speed to the successive passes of the sensor laterally to the stakes. Analysis of variance was used to test the influence of forward speed and stake widths as a function of the interval distance between obstacles.

Data collected were processed to calculate gaps as a percentage of total scanned row distance (Equation 1), and manual gap percentage was calculated as proposed by Stolf (1986), on Equation 2.

$$
\begin{aligned}
& G=\frac{d}{D F s} \times 100 \\
& G=\frac{\sum d}{\sum D F} \times 100
\end{aligned}
$$

where:

$\mathrm{G}$ - gaps (\%)

$\mathrm{d}$ - absence of stalks distance (m)

DFs - distance between starting gaps (m)

$\sum \mathrm{d}-$ sum of gaps $(\mathrm{m})$

$\sum \mathrm{DF}$ - total row measured.

In a preliminary test, the photoelectric sensor was directly measuring the absence of stalks in six $60 \mathrm{~m}$ long sugarcane rows. Gaps were also manually measured in the total extent of each row to evaluate the capability of the sensing system on detecting stalks gaps in percentage and comparing both systems.

Field tests were performed in new planted areas and after harvesting (regrowth conditions). These tests were run initially in three fields summing 17.2 ha with sugarcane planted around 90 days before, at $1.5 \mathrm{~m}$ row spacing, in a sugar mill area around Piracicaba, SP, Brazil (22 $33^{\prime} 27^{\prime \prime} ; 47^{\circ} 28^{\prime} 0^{\prime \prime}$ ) with the variety RB-855156. They were considered as areas P1 with 4.4 ha, P2 with 6.5 ha and $\mathrm{P} 3$ with 6.3 ha.

Plots of $6.0 \times 6.0 \mathrm{~m}$ (four crop rows) were allocated in the field in a grid of approximately four plots per hectare (Figure 2). The data values from each plot where selected and graphically delimited on a GIS (SST Software, Stillwater, Okla., USA).

Sugarcane gaps were manually measured on each plot, considering the maximum stalk distance of $0.5 \mathrm{~m}$ as the limit to do not be considered as a gap. The sensing system was installed on a tractor performing the row leveling operation, normally conducted around 90 days after planting, at speed of $1.7 \mathrm{~m} \mathrm{~s}^{-1}$, taking two rows each pass and measuring gaps in only one of the rows.

A ratoon sugarcane gaps evaluation was performed in another field in the same region ( $\left.22^{\circ} 33^{\prime} 22^{\prime \prime} ; 47^{\circ} 28^{\prime} 0^{\prime \prime}\right)$ at a first ratoon sugarcane with $1.5 \mathrm{~m}$ of row spacing, 90 days after harvest. The sampled area of approximately 20 ha was evaluated alternately the rows, also with manual evaluation performed in sampling plots of $6.0 \times 6.0 \mathrm{~m}$ with a density of one sample for each two ha. This area was identified as R1.

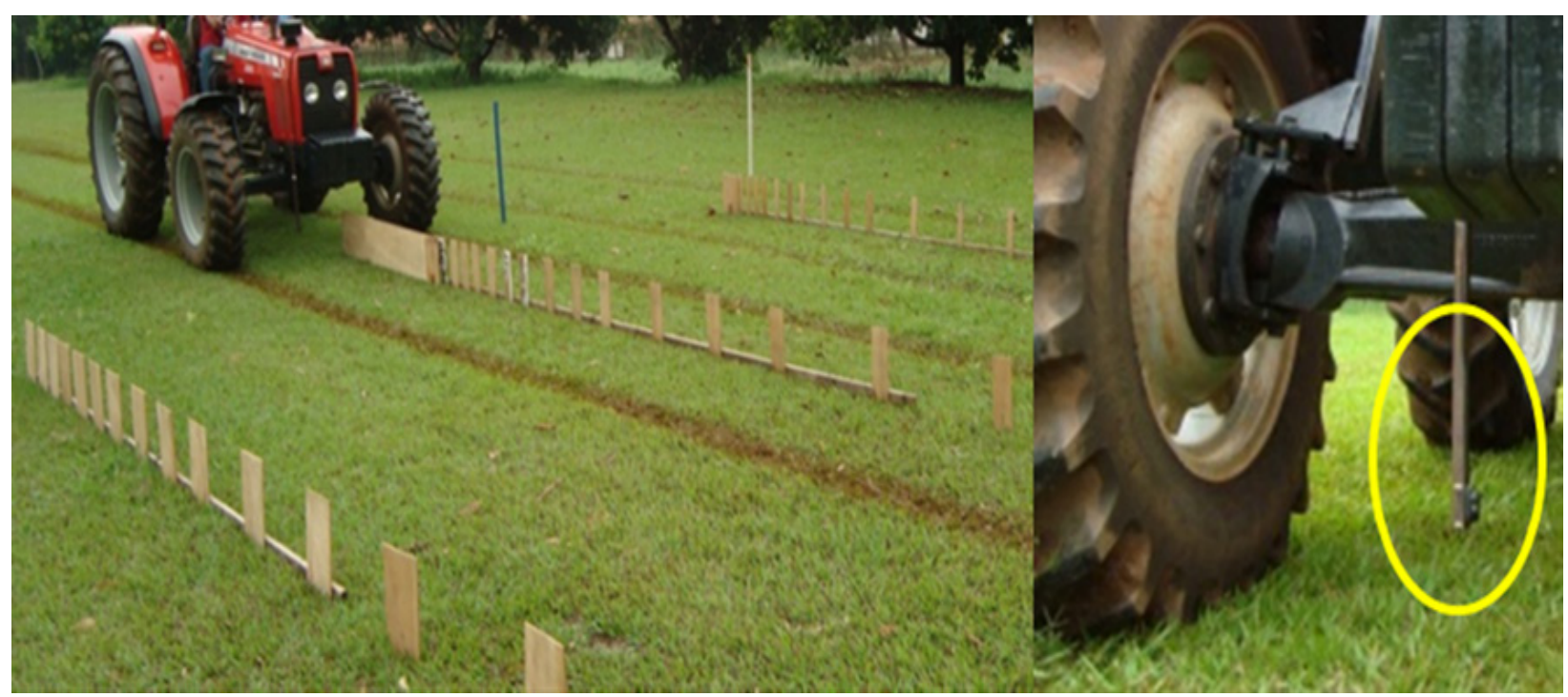

Figure 1: Test using regular obstacles simulating stalks (left) and photoelectric sensor positioned underneath and in front of the tractor (right). 
All data were analyzed by a Student T-test to compare samples by pair and show the existence of a correlation among the sensor and manual collected data. A descriptive data assessment was performed and, although some values appear like outliers, values bigger than 2 times the standard deviation $(2 \sigma)$ were removed.

Exploratory data analysis includes the determination of number of observations, minimum, maximum, mean, standard error, standard deviation, 25 percentile, 75 percentile, skewness, kurtosis (skewness is a measure of asymmetry of the data set distribution and kurtosis is a measure of whether the data are peaked or flat relative to a normal distribution). Also, a coefficient of correlation (r) were used to show the correlation between sensor and manually measured gaps.

To express the information by maps, the collected data of gaps were used in distance (meters) to show a proxy of how the gaps are shown in the field, without the purpose to compare them with the manual measurement. The Quantum GIS (QGIS, 2015) software environment was used to interpolate the data using the inverse of the distance, creating the maps of sugarcane gaps in the assessed fields.

\section{RESULTS AND DISCUSSION}

\section{Controlled tests}

Preliminary tests in laboratory indicated that the sensor can take up to four readings per second and the minimum distance reading between obstacles was 5 pulses, corresponding to $0.07 \mathrm{~m}$. It may be increased with changes on the encoder, increasing its sensitivity. Validation tests, using regular obstacles simulating stalks, showed the photoelectric measurements accuracy presenting errors between 0.02 and $0.03 \mathrm{~m}$ under speeds varying in 1.3, 2.0 and $3.0 \mathrm{~m} \mathrm{~s}^{-1}$ and obstacles ranging from 0.1 to $1.0 \mathrm{~m}$ of gap (Figure 3). At this stage, the correlation between stakes arrangement and sensor measured distances was close to 1 demonstrating good measurement accuracy.

Results of tests performed at sugar cane rows are shown at Table 1, where it is shown the percentage of gaps of manually sampling and measured by the sensor, and the percentage of photoelectric sensor gaps were close to those manually measured (presented as a percentage of the total

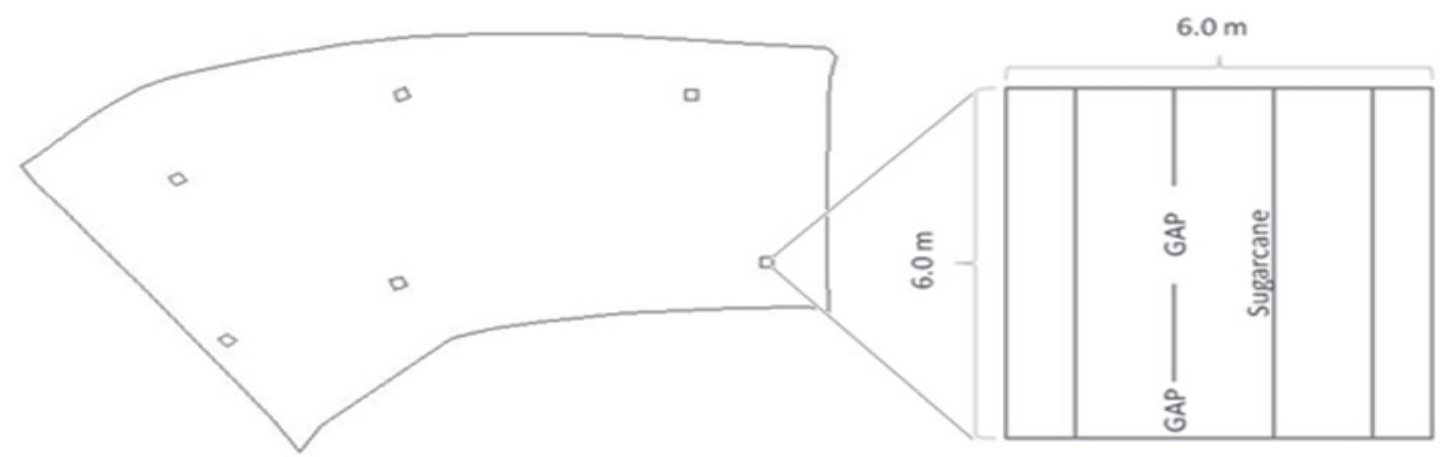

Figure 2: Example of individual plots location in the field.
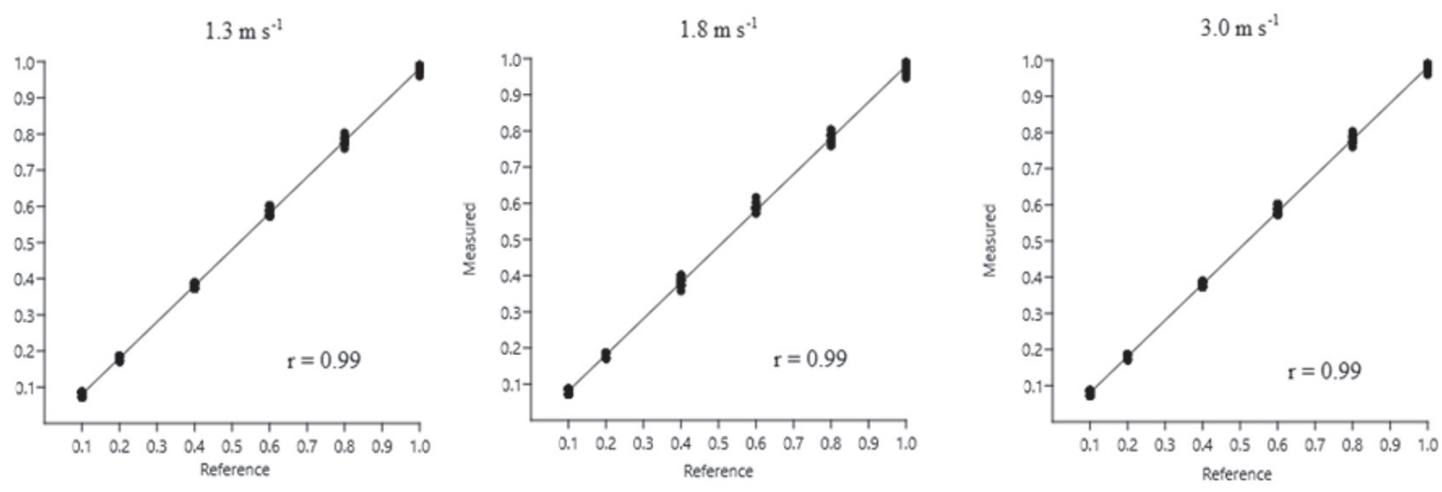

Figure 3: Correlation between photoelectric measurements and stakes distances, from obstacles ranging from 0.1 to $1.0 \mathrm{~m}$ of gaps, obstacles widths of $0.05,0.10$ and $0.20 \mathrm{~m}$ and under forward speeds varying from $1.3,1.8$ and $3.0 \mathrm{~m} \mathrm{~s}^{-1}$. 
length of the rows with $60 \mathrm{~m}$ ). This gives an indication that the system was able to work fine under field conditions.

\section{Field tests}

The system was submitted to field work and Table 2 shows the statistics of gaps counted on the experimental plots along the planted and first ratoon areas. Under field conditions the results indicated no statistical differences between manual or sensor measuring methods (Student T-test) and the coefficient of correlation $r$ (Figure 4) values were 0.80 on the planted fields and 0.66 on the regrown area (first ratoon).

The system measures gaps and replaces the current method of manual monitoring with the advantage of intensive sampling, higher data density and faster measuring process. It can be mounted in any vehicle that will travel along the field during the growing season for any operation.
Newly planted areas showed better results than on the first ratoon field and both resulted in good correlation between manual and sensor methods of gaps measurement at sugarcane fields. The minimum considered as a sugarcane gap was established as $0.5 \mathrm{~m}$, based on the encoder configuration and wheel diameter, which may change. A better GNSS signal can be used for distance measurement instead of the encoder, with a higher location accuracy of each gap.

The height between ground and sensor may cause some noise as it senses some sugarcane leaves and not only stalks. The arrangement of leaves on planted and on regrowth areas is different, false scanning can happen if the area is infested with weed or other obstacles like standing residues, indicating the necessity of attention while positioning the sensor relative to the ground.

The photoelectric sensor has the capacity of collecting continuous data and, with the processing and georeferencing, the starting point of each gap can be

Table 1: Distances without stalks measured by the photoelectric sensor in the test area of six $60 \mathrm{~m}$ sugarcane rows.

\begin{tabular}{|c|c|c|c|}
\hline \multirow{2}{*}{ Row } & \multicolumn{2}{|c|}{ Gaps (\%) } & \multirow{2}{*}{ Correlation (r) } \\
\hline & Mannually measured & Sensor measured & \\
\hline 1 & 41.3 & 46.3 & \multirow{6}{*}{$0.99 *$} \\
\hline 2 & 46.3 & 50.7 & \\
\hline 3 & 23.8 & 21.8 & \\
\hline 4 & 31.3 & 28.1 & \\
\hline 5 & 26.2 & 24.8 & \\
\hline 6 & 46.3 & 54.8 & \\
\hline
\end{tabular}

* $p$ value $=0,05$.

Table 2: Statistical summary of results from planted and first ratoon areas (\%).

\begin{tabular}{crrrr}
\hline \multirow{2}{*}{ Statistics } & \multicolumn{2}{c}{ Planted areas } & \multicolumn{2}{c}{ First ratoon area } \\
\cline { 2 - 5 } & Manual & Sensor & Manual & Sensor \\
\hline $\mathrm{N}$ & 70.00 & 70.00 & 19.00 & 19.00 \\
Min $(\mathrm{m})$ & 11.00 & 8.70 & 4.70 & 1.90 \\
Max $(\mathrm{m})$ & 53.70 & 55.00 & 81.90 & 71.60 \\
Mean $(\mathrm{m})$ & 28.49 & 27.15 & 25.21 & 35.63 \\
Std. error $(\mathrm{m})$ & 1.15 & 1.14 & 4.17 & 4.20 \\
Stand. dev $(\mathrm{m})$ & 9.66 & 9.55 & 18.17 & 18.33 \\
25 prcntil $(\mathrm{m})$ & 21.08 & 19.70 & 16.10 & 19.70 \\
75 prcntil $(\mathrm{m})$ & 33.05 & 33.12 & 35.40 & 52.90 \\
Skewness & 0.59 & 0.55 & 1.92 & 0.04 \\
Kurtosis & 0.18 & 0.31 & 4.40 & -0.59 \\
\hline
\end{tabular}


shown in a map (Figure 5). In manual measurements, only portions of sampling rows are monitored, and the result is an average number from local readings. A detailed resolution obtained from photoelectric sensors allows a better way to decide which area has to be replanted in fields that were just planted or renovated if injuries compromise the crop economical threshold.

Usually, sugarcane replanting is done based on yield drop (Keerthipala; Dharmawardene, 2000) and there is not much in the literature relating gaps and yield. Certainly, georeferencing gaps, their intensity and extension, and displaying them in a map, allows a useful tool, which can

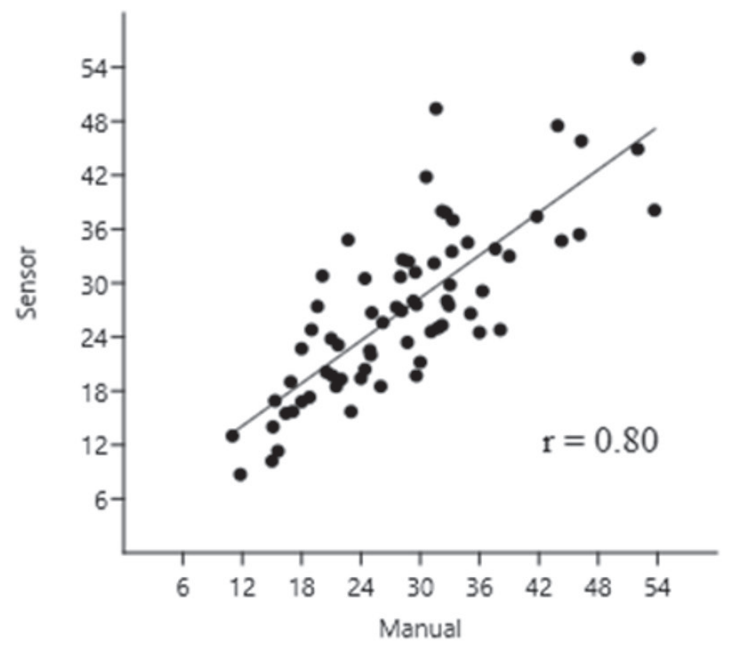

lead to better management by acquiring complementary information about the field, like problems related to erosion, pests and others, showing more precisely where to act, saving labour and time.

Table 3 shows the statistics of individual gaps to the four assessed areas after removing gaps larger than $2 \sigma$.

The histograms of gaps on each field (Figure 6) show that most of the data are concentrated on the minimum and barely reach values over $5 \mathrm{~m}$ in the planted areas, but the area on its second cut (R1) shows often larger gaps, indicating damages on the sugarcane fields, as the areas are getting older and with more ratoons.

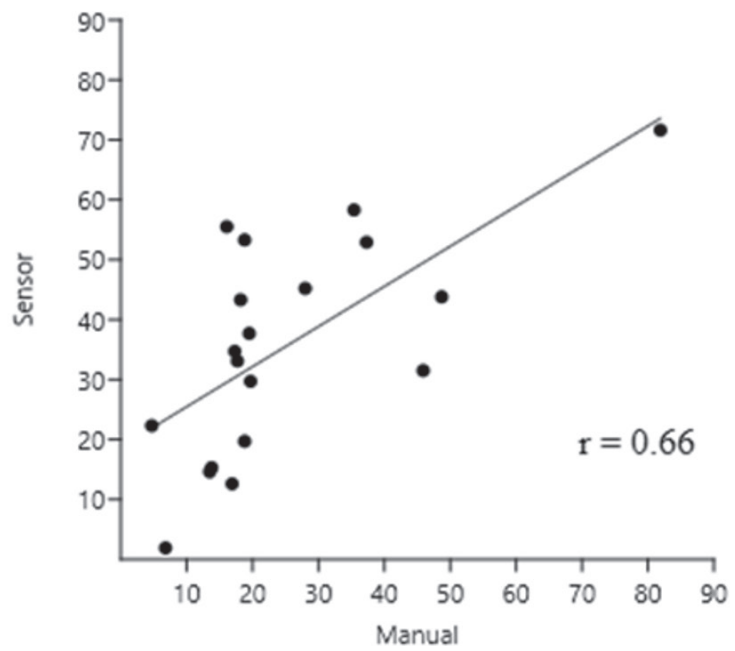

Figure 4: Correlation between gaps measured manually and by the sensor system on plant crops (left) and first ratoon crops (right).

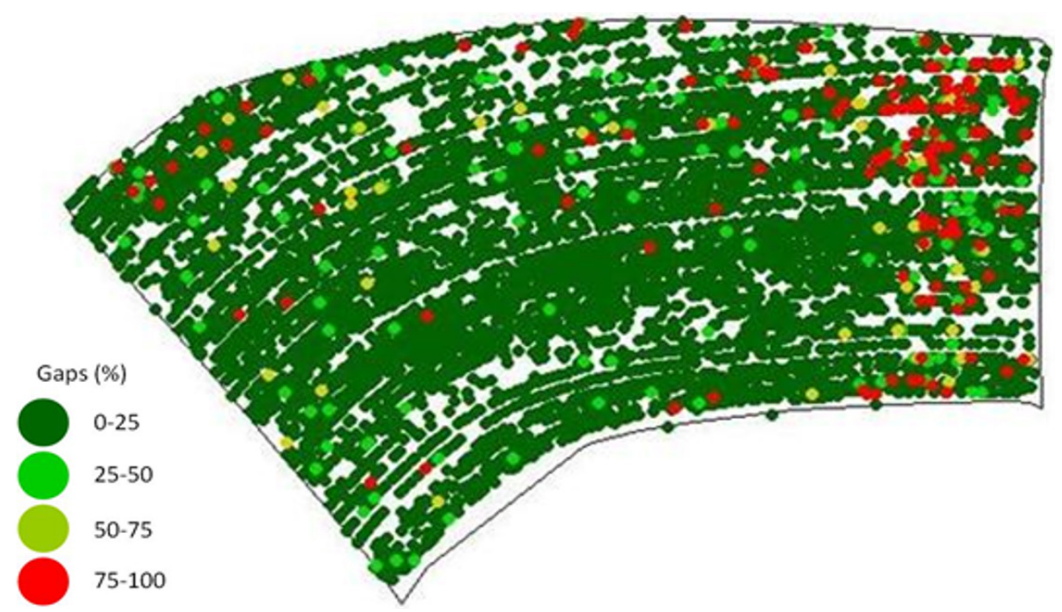

Figure 5: Illustration of a field of 20 ha showing an area on the right-hand with larger gaps (points in red represent locations with more than $75 \%$ gap). 
Table 3: Statistical summary of individual gaps along the four experimental areas.

\begin{tabular}{crrrrr}
\hline & \multicolumn{1}{c}{ P1 } & \multicolumn{1}{c}{ P2 } & \multicolumn{1}{c}{ P3 } & \multicolumn{1}{c}{ R1 } & \multicolumn{1}{c}{ Total } \\
\hline Gaps & $3,137.00$ & $3,935.00$ & $4,253.00$ & $19,410.00$ & $30,735.00$ \\
Min (m) & 0.52 & 0.52 & 0.52 & 0.52 & 0.52 \\
Max (m) & 2.24 & 2.30 & 3.02 & 22.29 & 22.29 \\
Mean (m) & 0.99 & 0.95 & 1.14 & 2.65 & 1.43 \\
Std. Error (m) & 0.01 & 0.01 & 0.01 & 0.02 & - \\
Stand. Dev (m) & 0.38 & 0.42 & 0.60 & 3.42 & - \\
Median (m) & 0.86 & 0.80 & 0.94 & 1.35 & - \\
25 prcntil (m) & 0.68 & 0.62 & 0.67 & 0.82 & - \\
75 prcntil (m) & 1.19 & 1.16 & 1.44 & 2.74 & - \\
Skewness & 1.15 & 1.23 & 1.18 & 2.92 & - \\
Kurtosis & 145.73 & 327.80 & -573.11 & $232,916.60$ & - \\
Area (ha) & 4.40 & 6.50 & 6.30 & 25.00 & 42.20 \\
Gaps ha-1 & 712.95 & 605.38 & 675.08 & 776.40 & 728.32 \\
\hline
\end{tabular}
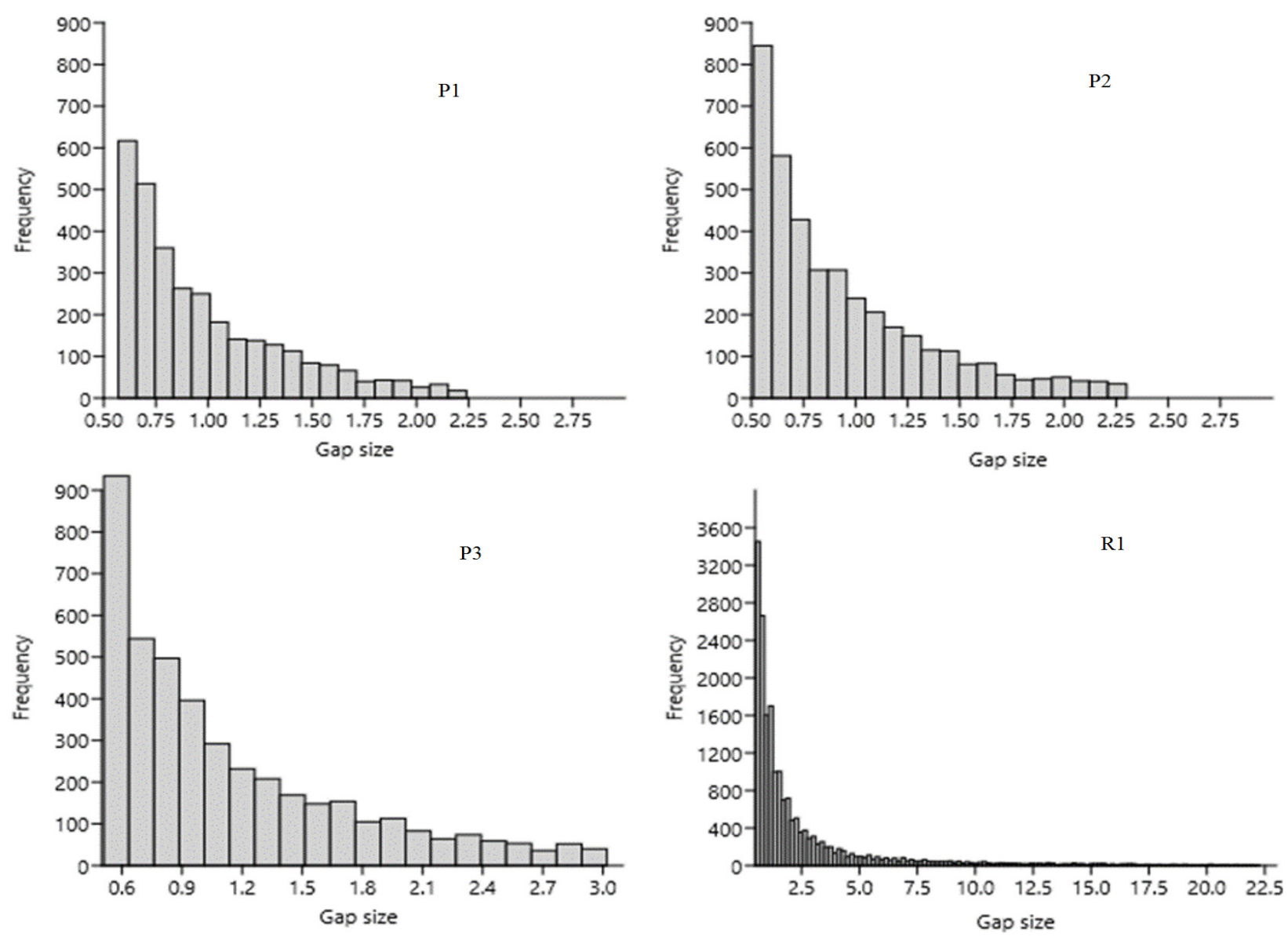

Figure 6: Histograms of gap frequency to all tested areas. 


\section{Map development}

The interpolated maps with pixels of $2 \times 2 \mathrm{~m}$ are presented on Figure 7. The newly planted areas maps show smaller gaps than the first ratoon field. It is expected that the intensity and extension of gaps will increase every year and this is the information the manager needs to make decisions regarding some mitigation from localized planting or the total replanting. The first ratoon field map indicates that most of the area has a tendency to present gaps between 0 and $5 \mathrm{~m}$, but there is a concentration of bigger gaps on the northeast of the assessed area following the plants rows. On the south edge, it is possible to identify a continuous area with bigger gaps. On both, gaps could have started at planting or happened during the first growing and harvesting cycle.

Some spots with slightly high gaps can be identified on areas $\mathrm{P} 1, \mathrm{P} 2$ and $\mathrm{P} 3$; gaps here are more randomly distributed. Mainly in P3, there is a trend in the south part of the field, but there is no indication of long lines of gaps. On the area R1, some bigger gaps start to appear clearly in the west side. They are the result of accumulation of gaps from planting, mechanical harvesting, traffic, pests, drought and others.
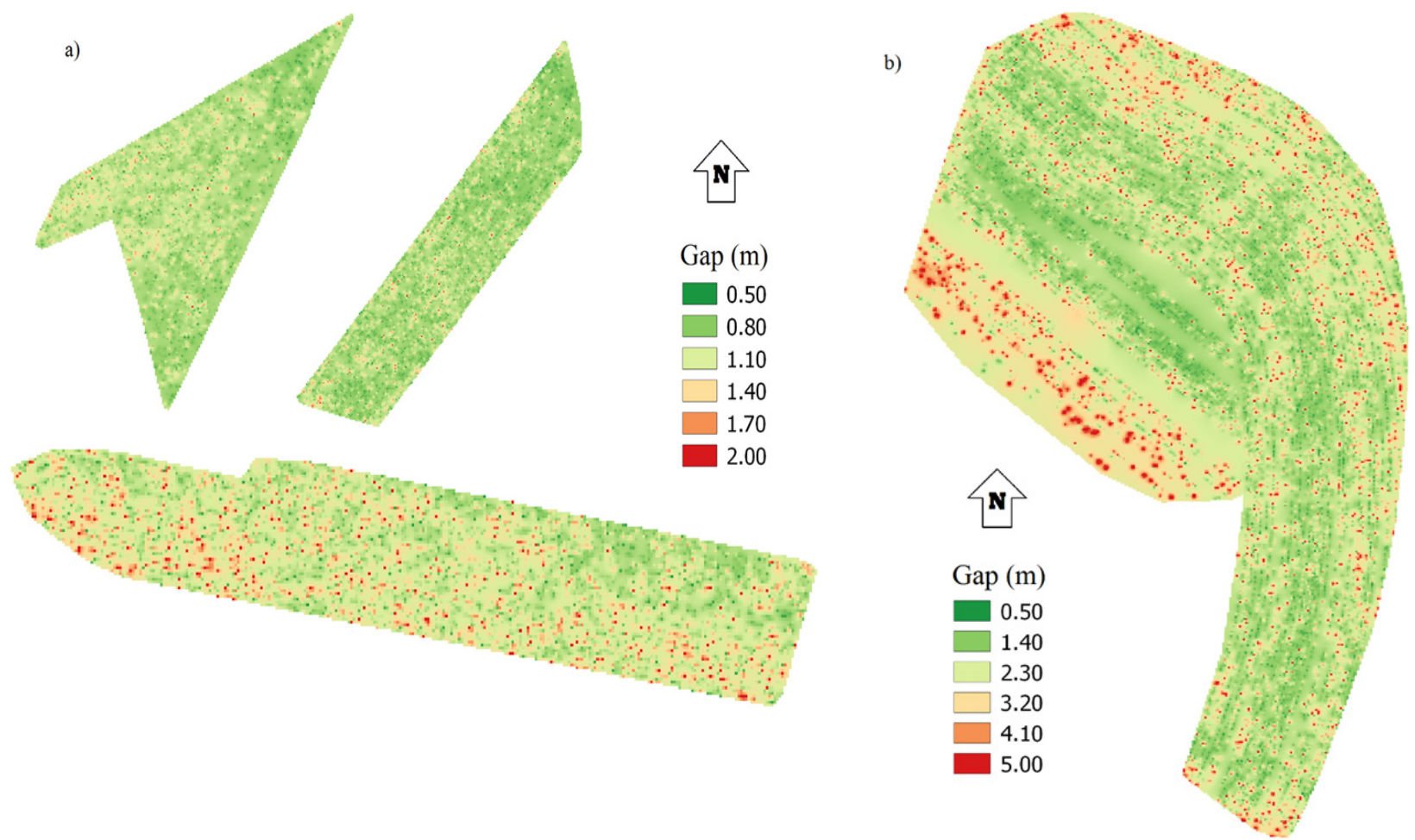

Figure 7: Maps of sugarcane gaps on P1, P2 and P3 areas (a) and on R1 (b). 


\section{CONCLUSIONS}

The photoelectric sensor system developed and tested measures gaps and replaces the current method of manual monitoring with the advantage of intensive sampling and higher information density. It can be mounted in any vehicle that is traveling on the field during the growing season for any other operation. The information acquired of sugarcane gaps can be represented in maps allowing the visualization of areas which demand local intervention after planting or a decision for replanting the entire area when a threshold gap is reached.

\section{ACKNOWLEDGEMENTS}

To Grupo São Martinho for the field work support and to FINEP (Brazilian Ministry of Science and Technology) Proj. No. 01.08.0566.00 for their financial support.

\section{REFERENCES}

EMPRESA DE PESQUISA ENERGÉTICA - EPE. National energy balance 2015: Year base 2014. Rio de Janeiro: EPE. 2015. Available in: <https://ben.epe.gov.br/>. Access in: August, $12,2015$.

FOOD AND AGRICULTURE ORGANIZATION - FAO. Faostat, 2013. Available in: <http://faostat.fao.org>. Access in: March 4, 2014.

FRASSON, F. R. et al. Use of active optical sensor to detect gaps on sugarcane planting. STAB, 26:34-37, 2007.

JOHANSEN, K., et al. Mapping whitegrub damage in sugarcane from high spatial resolution satellite imagery. SouthEastern European Journal of Earth Observation and Geomatics, 3(2):549-553, 2014.

KEERTHIPALA, A. P.; DHARMAWARDENE, N.. Determination of optimal replanting cycles for sugarcane production in Sri Lanka. Sugar Cane Tech, 2(3):9-19, 2000.

MA, S. et al. Sugarcane harvester technology: a critical overview. Applied Engineering in Agriculture, 30(5):727739, 2014.

MANHÃES, C. M. C. et al. Quantitative damages to ratoon in the sugarcane harvest in North Fluminense. Vértices, 15(3):61-71, 2013.

NAKARMI, A. D.; TANG, L. Automatic inter-plant spacing sensing at early growth stages using a 3D vision sensor. Computers and electronics in agriculture, 82:23-31, 2012.
NORONHA, R. H. F, et al. Statistical control applied to the diurnal and nocturnal mechanized harvesting process in sugarcane. Bragantia, 70(4):931-938, 2011.

OTTO, R. et al. High soil penetration resistance reduces sugarcane root system development. Soil and Tillage Research, 117:201-210, 2011.

PACCA, S.; MOREIRA, J. R. Historical carbon budget of the Brazilian ethanol program. Energy Policy, 37(11), p. 48634873, 2009.

PAULA, V. R.; MOLIN, J. P. Assessing damage caused by accidental vehicle traffic on sugarcane ratoon. Applied Engineering in Agriculture, 29(2):161-169, 2013.

QGIS Development Team. QGIS Geographic Information System. 2015, Open Source Geospatial Foundation Project. Available in: <http://qgis.osgeo.org>. Access in: 2015.

RUDORFF, B. F. T. et al. Studies on the rapid expansion of sugarcane for ethanol production in São Paulo State (Brazil) using Landsat data. Remote sensing, 2(4):1057-1076, 2010.

SANTOS, M. A. et al. Rating failures the sprouting of sugarcane as a function of water availability. Agropecuária Científica no Semiárido, 9(4):30-35. 2013

SERAFIM, L. G. F. et al. Influence of mechanical planting in the budding index of sugarcane. STAB, 31(1):22-25, 2013.

SHI, Y. et al. Improvement of a ground-LiDAR-based corn plant population and spacing measurement system. Computers and Electronics in Agriculture.112:92-101, 2015.

SOUZA, G. D. et al. Soil compressibility and root system of sugarcane with and without controlled-traffic farming. Pesquisa agropecuária brasileira, 47(4):603-612, 2012.

STOLF, R. Methodology for gap evaluation on sugarcane lines. STAB, 4(6):12-20, 1986.

TOLON-BECERRA, A. et al. Effects of different tillage regimes on soil compaction, maize (Zea mays L.) seedling emergence and yields in the eastern Argentinean Pampas region. Soil and Tillage Research. 117:184-190, 2011.

WANG, L., et al. Economic and GHG emissions analyses for sugarcane ethanol in Brazil: Looking forward. Renewable and Sustainable Energy Reviews, 40:571-582, 2014. 